\title{
UDC 541.64: 547:512 \\ COPOLYMERIZATION OF CYCLOPROPYL STYRENE AND ITS MONO- AND GEMDICHLORODERIVATIVES WITH METHACRYLIC ACID
}

\author{
S.B. Mamedli \\ Institute of Polymer Materials of the National Academy of Sciences of Azerbaijan \\ A3 5004 Sumgait, S.Vurgun Str., 124, e-mail: ipoma@ science.az \\ Tel.: 0557441355, e-mail: seide.mamedli@yandex.ru
}

Received 13.12.2019

\begin{abstract}
The radical copolymerization of p-cyclopropyl styrene (1) and its monochloro-(II) and gemdichloro-substituted derivatives with methacrylic acid was carried out. The composition and structure of these copolymers was established. It revealed that the copolymerization reactions proceed with opening of double bond of the vinyl group (I-III) of monomers and methacrylic acid. Also, copolymerization constants were determined and $Q-e$ parameters on Alfrey-Price and copolymer microstructure calculated. It found that the synthesized copolymers were characterized by effective light transmission (88-90\%) and optical index.
\end{abstract}

Keywords: p-cyclopropyl styrene, copolymerization, monochloro-p-cyclopropyl styrene, gemdichloro-pcyclopropyl styrene, microstructure, optically transparent materials

DOI: $10.32737 / 2221-8688-2020-1-78-82$

\section{Introduction}

Modern technologies in opto- and microoptoelectronics, optics, medicine and other branches make special requirements for synthetic materials. Therefore, the interest of manufacturers in new equipment and materials for poly-functional monomers, oligomers, polymers and copolymers based thereon is constantly growing. In this respect crucial role goes to polymers and styrene copolymers and their derivatives [1-3]. One of the ideal derivatives of styrene in terms of optically transparent homo- and copolymer creation are functionally substituted cyclopropyl styrenes [4]. An availability of functionally substituted cyclopropyl substituents with interesting structure and properties enhance optical and photosensitive properties of the obtained highmolecular compounds, contribute to various chemical conversions and as a result makes it possible to obtain the polymeric materials with appropriate properties. However, transparent polystyrene has the following disadvantages: fragility, low adhesion, instability to UV-rays. One of the ways of problem resolution is the preparation of new copolymers of styrene and its derivatives with other, primarily polar monomers. In this aspect the ideal comonomers are methacrylic monomers [5].

This paper has been devoted to the results of the investigation of regularities of the copolymerization of chloro-substituted cyclopropyl styrenes with methacrylic acid (MAA).

The aim of this work - revealing of some regularities of the radical copolymerization of p-cyclopropyl styrene (I) and its monochloro- (II) and gemdichlorosubstituted derivatives (III) with methacrylic acid (MAA). The obtained polyfunctional copolymers can be used in the further chemical conversions. In addition, it is known that the chlorine-containing cyclopropane compounds are suitable for preparation of biologically active compounds.

\section{Experimental}

The synthesis of p-cyclopropyl styrene (I) and its monochloro- (II) and gemdichlorosubstituted derivatives (III) was carried out in line with previously described methodology [6]. The copolymerization reaction (I-III) with MAA was realized in ampoules in the benzene solution in the presence of freshly-crystallized initiator AIBN and the quantity of $0.2 \mathrm{~mol} \%$ from total mass of comonomers at $70^{\circ} \mathrm{C}$. The obtained 
copolymers were purified by two-fold precipitation from benzene solutions with pentane and dried to a constant mass at $30^{\circ} \mathrm{C}$ in vacuum (15-20 $\mathrm{mm}$ merc.c.). Copolymers composition was calculated due to chemical analysis of carboxyl group, and for copolymers (II-III) + MAA - elemental analysis for chlorine content. In the processes for which constants were calculated, the conversion of comonomers made up 8-10\%.

The obtained copolymers are transparent powdery products, well soluble in dioxane and acetone. Characteristic viscosity for copolymers (I-III) + MAA was determined in dioxane in Ubbelohde viscometer at $20^{\circ} \mathrm{C}([\eta]$ $=0.95-1.1 \mathrm{dl} / \mathrm{g})($ Table 2). The parameters of copolymer microstructure were determined by means of equation presented in work [7].

The IR spectra of the initial monomers and synthesized copolymer were registered on spectrometer "Agilent Cary 630 FTIR" of firm "Agilent Technologies", and the PMR spectra on spectrometer "Fourier" of firm "Bruker" (FRG) (300.18 MHz) in dioxane solution.

The refractive index was determined using a device Anton Paar Abbemat 200.

\section{Results and discussion}

With the aim of determination of influence of the initial concentration of the monomer mixture on composition of forming copolymers the copolymerization reaction was carried out at various ratios of the initial comonomers. The molar fractions of the corresponding links ( $\mathrm{m} 1$ and $\mathrm{m} 2$ ) have been found on content of carboxyl groups and chlorine atom in the copolymer composition (Table 1 ).

The copolymerization constants of system (I-III) + MAA have been determined by Fineman-Ross method [8] and the values of Q-e parameters on Alfrey-Price have been calculated (Table $1)$.

Table 1. Conditions of preparation, compositions and parameters of copolymer microstructures of cyclopropyl styrene (I) and its 2-chloro-(II) and 2,2-dichloro-(III) substituted derivatives $\left(\mathrm{M}_{1}\right)$ with methacrylic acid $\left(\mathrm{M}_{2}\right) \cdot \mathrm{t}=70^{\circ} \mathrm{C}$, initiator $\mathrm{AIBN}(0,2$ mol \% from total mass of the comonomers).

\begin{tabular}{|c|c|c|c|c|c|c|c|c|c|}
\hline \multirow[t]{2}{*}{ Monomers } & \multicolumn{2}{|c|}{$\begin{array}{c}\text { Initial } \\
\text { mixture, } \\
\text { mol \% }\end{array}$} & \multicolumn{2}{|c|}{ Content } & \multicolumn{2}{|c|}{$\begin{array}{c}\text { Copolymer } \\
\text { composition, } \\
\text { mol \% }\end{array}$} & \multicolumn{3}{|c|}{ Microstructure } \\
\hline & $\mathrm{M}_{1}$ & $\mathrm{M}_{2}$ & Cl, \% & $\mathrm{COOH}, \%$ & $\mathrm{~m}_{1}$ & $\mathrm{~m}_{2}$ & $\mathrm{~L}_{\mathrm{M}_{1}}$ & $\mathrm{~L}_{\mathrm{M}_{2}}$ & $\mathrm{R}$ \\
\hline \multirow[b]{5}{*}{ (I) $\searrow$} & 10 & 90 & \multirow{5}{*}{-} & 36.64 & 20.35 & 79.65 & 1.06 & 4.15 & 38.38 \\
\hline & 25 & 75 & & 34.05 & 36.51 & 63.49 & 1.18 & 2.05 & 61.91 \\
\hline & 50 & 50 & & 17.98 & 53.28 & 46.72 & 1.54 & 1.35 & 69.20 \\
\hline & 75 & 25 & & 10.63 & 70.06 & 29.94 & 2.62 & 1.11 & 53.53 \\
\hline & 90 & 10 & & 5.01 & 84.94 & 15.06 & 5.86 & 1.03 & 28.99 \\
\hline \multirow[b]{5}{*}{ (II) $\overbrace{\mathrm{Cl}}$} & 10 & 90 & 7.8 & 36.08 & 21.18 & 78.82 & 1.066 & 3.97 & 39.71 \\
\hline & 25 & 75 & 12.35 & 26.10 & 37.5 & 62.5 & 1.19 & 1.99 & 62.71 \\
\hline & 50 & 50 & 14.35 & 21.84 & 45.45 & 54.55 & 1.6 & 1.33 & 68.25 \\
\hline & 75 & 25 & 19.93 & 10.02 & 71.6 & 28.4 & 2.8 & 1.10 & 51.28 \\
\hline & 90 & 10 & 22.47 & 4.61 & 86.06 & 13.94 & 6.4 & 1.03 & 26.91 \\
\hline \multirow[b]{5}{*}{ (III } & 10 & 90 & 8.03 & 35.26 & 22.42 & 77.58 & 1.068 & 3.7 & 41.49 \\
\hline & 25 & 75 & 12.7 & 25.35 & 38.84 & 61.16 & 1.20 & 1.9 & 64.51 \\
\hline & 50 & 50 & 16.66 & 16.95 & 55.48 & 44.52 & 1.62 & 1.3 & 68.49 \\
\hline & 75 & 25 & 20.0 & 9.77 & 72.23 & 27.77 & 2.86 & 1.09 & 50.51 \\
\hline & 90 & 10 & 22.5 & 4.48 & 86.43 & 13.57 & 6.58 & 1.03 & 26.28 \\
\hline
\end{tabular}


The calculation of the average statistical length $\bar{L}$ of links (I-III) + MAA fulfilled according to the equation given in [7], at degrees of conversion not more than $10 \%$ showed that for studied systems in a wide range of compositions (90:10 - 20:80) a value $\bar{L}$ of the monomers (I-III) and MAA close to unit is observed (Table 1). The values of azeotropic copolymer compositions are also close for studied systems ( $\sim 55 \mathrm{~mol} \%$ for IIII). The low values $\bar{L}$ indicate to relative regularity of distribution of links of the comonomers on macromolecular chain, hence it follows that in the chosen conditions of copolymerization it can be obtained the copolymers with uniform distribution of various structural units on macromolecular chain.

It turned out that the copolymerization constants values $r_{1}$ and $r_{2}$ of the investigated system evidence about larger activity of
DCCPS than MAA $\left(r_{1}>r_{2}\right)$ (Table 2). This is has been obviously connected with influence of the chlorine atoms located at the cyclopropane ring on the vinyl group through a three-membered cycle and an increase of a degree of conjugation in the monomer molecule. This fact is confirmed by the data of UV spectrum of the monomer of DCCPS [9]. It has been seen from found copolymerization constant values that for systems (I-III) + MAA both types of formed radicals react more faster with "foreign" monomer than with their "own", and in the formation of macromolecules of copolymers are inclined to links alternation $\left(r_{1} \cdot r_{2}<<1\right)$. The main reason of such phenomenon, as is known, is the difference in the polarity of monomers and radicals formed from them. The inclination to alternation of monomer links in the macromolecule of copolymers with MAA grows in a series $\mathrm{I}<\mathrm{II}<\mathrm{III}$.

Table 2. Values $r_{1}$ and $r_{2}$ and $Q$ and $e$ parameters for systems (I-III) + MAA

\begin{tabular}{|c|c|c|c|c|c|c|}
\hline Monomers & $r_{1}$ & $r_{2}$ & $r_{1} \cdot r_{2}$ & $Q_{1}$ & $e_{1}$ & {$[\eta], \mathrm{dl} / \mathrm{g}$} \\
\hline I & 0.54 & 0,35 & 0.189 & 0.553 & -0.640 & 0.95 \\
\hline II & 0.60 & 0.33 & 0.198 & 0.637 & -0.621 & 0.98 \\
\hline III & 0.62 & 0.3 & 0.186 & 0.628 & -0.646 & 1.1 \\
\hline
\end{tabular}

The structure of copolymers obtained from monomers (I-III) + MAA under the conditions of radical polymerization was proved through comparing IR and PMR spectra of initial monomers and copolymers synthesized thereon.

The structural investigation of copolymers showed that the absorption bands at $1500-1605 \mathrm{~cm}^{-1}$, in the field of 1040-1045 $\mathrm{cm}^{-1}$ and $3400 \mathrm{~cm}^{-1}$ characteristic of benzene ring, cyclopropane and carboxyl groups, respectively, were kept after copolymerization. In the IR spectra of copolymers obtained from monomers II-III, there were absorption bands in the field of 640-750 $\mathrm{cm}^{-1}$ characteristic for $\mathrm{C}-\mathrm{Cl}$ bond.

The structure of the elementary structural fragments of macromolecules chain was also confirmed by PMR spectra. In the PMR spectra of copolymers the signals characteristic for protons of aromatic nucleus at 6.60-7.30 ppm, for carboxylic group 9.0$12.2 \mathrm{ppm}$ and for cyclopropane ring at 0.65 $1.66 \mathrm{ppm}$ were detected.

An absence of the absorption band at $1640 \mathrm{~cm}-1$, stipulated by vibrations of the vinyl group in the IR-spectrum, and also the signal at $\delta=5.7-6.41 \mathrm{ppm}$ corresponding to double bonds of the vinyl group in the PMR spectra of the comonomers confirm that the copolymerization proceeds on double $\mathrm{C}=\mathrm{C}$ bond of the comonomers.

A scheme of preparation reaction of copolymers of monomers (I-III) + MAA can be presented as follows: 



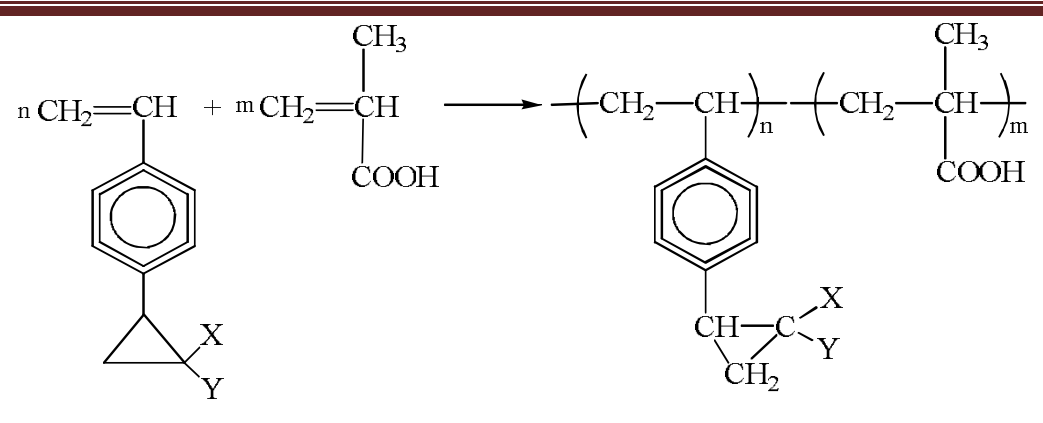

$\mathrm{X}=\mathrm{Y}=\mathrm{H}(\mathrm{I}) ; \mathrm{X}=\mathrm{Cl}, \mathrm{Y}=\mathrm{H}$ (II); $\mathrm{X}=\mathrm{Y}=\mathrm{Cl}$ (III).

The phenyl and cyclopropane fragments, as well as halogen atoms hinder the ordered arrangement of macromolecules and, as a result, the generation of crystalline formations. Due to its structural peculiarities the synthesized copolymers have good optical properties

$$
\mathrm{n}_{\mathrm{d}}^{20}=1,610-1,620 \text {. }
$$

It found that the synthesized copolymers have good light transmission (88-90\%).

It follows from obtained data that an increase of content of (I-III) monomers in the copolymers leads to considerable increase of

optical, physical-mechanical and heat-physical properties and rise in content MAA favors the increase of hardness and rigidity.

It revealed that copolymers of $\mathrm{p}$ cyclopropyl styrene (I) and its monochloro(II) and gemdichlorosubstituted derivatives (III) with methacrylic acid have high optical properties. In addition, the copolymers containing chlorine atoms in macromolecules display high biological activity. Obtained copolymers can be used as optically transparent materials in optics, medicine, optotechnology, and also in preparation of other optical products.

\section{Conclusions}

1. Radical copolymerization of p-cyclopropyl styrene (I) and its monochloro- (II) and gemdichlorosubstituted derivatives (III) with methacrylic acid was carried out. Copolymerization constants $\left(\mathrm{r}_{1}=0.54-0,62, \mathrm{r}_{2}=0.30-0.35\right)$ were determined, $\mathrm{Q}-\mathrm{e}$ parameters on Alfrey-Price $\left(\mathrm{Q}_{1}=0.553-0.637, \mathrm{e}_{1}=-0.640-(-0,646)\right.$ and copolymers microstructure calculated.

2. It was established that obtained copolymers had high optical transparency

$\mathrm{n}_{\mathrm{d}}^{20}=1,610-1,620$ and light transmission (88-90\%) which opens up the possibility of using them as optically transparent polymer materials.

\section{References}

1. Kuznetsov V.V, Sheremetyev S.V. Sensitive elements of optical sensors based on polystyrene with covalently immobilized reagents. J. of Analytical Chemistry. 2007, vol. 62, no. 3, pp. 303-311. (In Russian).

2. E.I. Shepurev, V. G. Rupyshev, V. M. Galperin, N. B. Kariglazova and others. Optical-mechanical industry. 1977, no. 11, pp. 36-37. (In Russian).

3. Rupyshev V.G., Ivanko T.P., Kozlova G.I. et al. Styrene copolymers with a refractive index of more than 1.6. Plast.massy-Poly
Plastic. 1983, no. 1, pp. 58-59. (In Russian).

4. Guliev K.G., Mamedli S.B., Guliev A.M. Synthesis and properties of cyclopropanecontaining optically transparent polymers. The Russian Journal Of Applied Chemistry. 2010, vol. 83, no.11, pp. 1889-1893.

5. Krul L.P., Matusevich Yu. I., Yakimtsova L. B., Butovskaya G.V. Chemical problems of creating new materials and technologies: collection of articles, vol. 3. Ed. O. A. Ivashkevich O.A. Minsk, 2008, pp. 422-446. (In Belarus). 
6. Guliyev K.G., Ischenko N.Ya., Guliyev A.M. Synthesis and polymerization of cyclopropyl styrene and its mono- and hemdichloro derivatives. Plast.massy-Poly Plastic. 2006, no. 12, p. 25. (In Russian).

7. Zilberman E.N. The microstructure parameters of multicomponent copolymers. 1979, Polymer Science. Series B Polymer Chemistry.1979, vol. 21, no. 1, pp. 33-36.
8. Fineman M., Ross S.D. J. Polym. Scl., 1950, vol. 5, no. 2, pp. 259.

9. Guliev K.G., Ponomareva G.Z., Mamedli S.B., Guliev A.M. Ultraviolet absorption spectra of 2-substituted-1- (n-vinylphenyl) cyclopropanes. Journal of Structural Chemistry. 2009, vol. 50, no. 4, pp. 720722. (In Russian).

\title{
TSIKLOPROPILSTİROL VO ONUN MONO-VO HEMDIXLOR TÖROMOLORINIIN METAKRIL TURŞUSU ILO BIRGOPOLIMERLOŞMOSI
}

\author{
S.B. Mommadli \\ AMEA Polimer materiallarl institutu \\ Az 5004 Sumqayıt, S.Vurğun küç., 124; e-mail: ipoma@ science.az
}

p-Tsiklopropilstirol (I) va onun monoxlor (II) va hemdixloravazli töramalarinin (III) metakril turşusu ila radikal birgapolimerlaşməsi həyata keçirilmişdir. Sintez olunmuş birgəpolimerlarin torkib va quruluşları müəyyən edilmişdir. Göstarilmişdir ki, birgapolimerlaşmə reaksiyası monomerlarin (I-III) va metakril turşusunun ikiqat rabitəsinin qırılması hesabına həyata keçir. Birgəpolimerlaşmə sabitlorinin qiymətləri tapılmış, Alfrey-Praysa göra Q-e parametrlari va birgapolimerlarin mikroquruluşu tayin edilmişdir. Müəyyən edilmişdir ki, sintez olunan birgapolimerlar yax̧̧ı işılqburaxma (88-90\%) va optiki şaffaflıq xassalari ila xarakteriza olunurlar.

Açar sözlar: p-tsiklopropilstirol, birgapolimerlaşma, monoxlor-p-tsiklopropilstirol, qemdixlor-ptsiklopropilstirol, mikroquruluş, optiki şaffaf materiallar.

\section{СОПОЛИМЕРИЗАЦИЯ ЦИКЛОПРОПИЛСТИРОЛА И ЕГО МОНО- И ГЕМДИХЛОРПРОИЗВОДНЫХ С МЕТАКРИЛОВОЙ КИСЛОТОЙ}

\section{С.Б. Мамедли}

Институт Полимерных Материалов Начиональной АН Азербайджана A3 5004 Сумгайыт, ул. С. Вургуна, 124, e-mail: ipoma@ science.az

Осуществлена радикальная сополимеризащия п-цุиклопропилстирола (I) и его монохлор- (II) $u$ гемдихлорзамещенных производных (III) с метакриловой кислотой. Установлены состав $и$ структура этих сополимеров. Показано, что реакции сополимеризации протекают с раскрытием двойной связи винильной группы (I-III) мономеров и метакриловой кислоты. Определены константы сополимеризации, рассчитаны параметры $Q-e$ по Алфрею - Прайсу и микроструктура сополимеров. Установлено, что синтезированные сополимеры характеризуются хорошим светопропусканием (88-90 \%) и оптическими показателями.

Ключевые слова: n-циклопропилстирол, сополимеризаиия, монохлор-n-ииклопропилстирол, гемдихлор-п-ииклопропилстирол, микроструктура, оптически прозрачные материалы 